\title{
XLVIII. On a change observed in the colour of Prussian blue by coming in contact with iron
}

\section{Thomas Gill Esq.}

To cite this article: Thomas Gill Esq. (1803) XLVIII. On a change observed in the colour of Prussian blue by coming in contact with iron , Philosophical Magazine Series 1, 16:63, 271-272, DOI: $10.1080 / 14786440308676341$

To link to this article: http://dx.doi.org/10.1080/14786440308676341

曲 Published online: 18 May 2009.

Submit your article to this journal $\lceil\pi$

Џll Article views: 3

Q View related articles $\square$ 
Change olserved in the Colour of Prussian Blue. 271

line humour is not of an uniform density throughout; it is therefore essential that attention be given to preserve that humour entire for this operation. I found the weight of a very fresh crystalline of an ox to be 30 grains; and its specific gravity was, as I before stated, 10765. I then pared away all the external part, in every direction, till there remained but 6 grains of the centre; and the specific gravity of these 6 grains I found to be 11940 . From this it would seem that the density increases gradually from the circum. ference to the centre.

It is not surprising that the crystalline humour should be subject to disorders, it being wholly composed of animal matter of the most perishable kind. Fourcroy says that it is sometimes found osseous in advanced age. Albumen is coagulated by many methods; and, if we suppose that the same changes can take place in the living eye as in the dead animal matter of the chemists, it will be easy to account for the formation of the cataract; a disorder which cannot be cured but by the removal of the opake lens, If a sufficient number of observations were made respecting the frequency of the cataract in gouty habits, some important conclusions might be drawn as to the influence of phosphoric acid in causing the disorder, by the common effect of acids in coagulating albumen.

XLVIII. On a Change olserved in the Colour of Prussian Blue by coming in Contact with Iron. By THomas GILL, Esq.

$\mathrm{H}^{\mathrm{siR},}$ To Mr. Tilloch.

Having frequently discoursed with you on the various colours producible from iron, I make no apology for troubling you with this letter. Happening this morning to be grinding some Chinese blue colour with parchment, size, and water, I noticed that a knife I cmployed in mixing it became of a greenish tinge: upon this I resolved to prosecute the experiment, when the following singular result was obtained :- After spreading a little of the colour upon the blade of the knife with a camel's hair pencil, I diluted and took off exough of the colour to form a tint upon paper, and as soon as that was laid on proceeded to take off a second, a third, \& c. portion, without adding more colour to the knife, until I had obtained thirty-six different tints, each varying 
varying in colour from the original blue. The changes were to a greenish blue, a green, an olive green, a yellowish green, a yellow, and so on to a buff colour, where I ceased from further prosecuting the search.

I then tried the same experiment with a cake of Newman's Prussian blue; and, repeating the process quicker, I obtained from the same original quantity of colour first laid on the knife no less than eighty-six different tints, each varying in colour as in the former experiment.

Indigo treated in a similar manner did not change its tint in the least degree under the process.

This discovery may lead to very important consequences in the theory of colour-making; and it furnishes some curious facts, namely, that the Chinese are acquainted with the art of making a colour similar to the Prussian blue; and that indigo should be preferred to the Prussian blue when we wish our colours to be durable, and not subject to change on coming in contact with iron : it should also serve as a caution never to employ the pallet knife or iron in any form in treating Prussian blue.

It would appear from the result of this experiment, either that the Prussic acid, one of the constituent principles of Prussian blue, is not saturated in that combination with iron, but is still able to exercise an action on that metal in its metallic state, or else that the acid itself becomes decomposed, giving up its oxygen to the iron, and producing the ochrey tint which changes gradually the blue to greell.

We are possessed of one tinge only of green colour produced from iron, namely, Prussian green, with the process for obtaining which I am unacquainted.

Allow me before concluding to mention another fact with which some of your readers may not be acquainted. The superiority of the Chinese colours over those of Europe is owing chiefly to their being ground much finer, and being mixed with size instead of gum, which prevents their having any gloss.

XILIX. On the Marine Speneer, invented by KNigst SPENCER, Esq.

$I_{N}$ our last Number we gave a short description of this inyention. To show its great utility, we need only to mention 2 few of the many possible cases in which it may be employed 